\title{
Entrepreneurial marketing: Between entrepreneurial personality traits and business performance
}

\author{
Endi Sarwoko, Iva Nurdiana Nurfarida
}

\begin{abstract}
Objective: Practices of traditional marketing cannot be fully applied to small and medium-sized enterprises (SMEs). SMEs owners have a responsibility to replace the practice with innovative behaviour such as entrepreneurial marketing (EM). This study examines the role of EM in business performance and the role of entrepreneurial personality traits as antecedents of EM.

Research Design \& Methods: A quantitative research approach was adopted with a questionnaire to collect data from 187 SMEs owner/managers in Indonesia. SEM-PLS analysis was used for hypothesis testing.

Findings: The results indicate that EM has a positive effect on business performance. SMEs owners/managers with the characteristics of extraversion, agreeableness, and conscientiousness can encourage the implementation of EM, which impacts business performance. Extraversion, conscientiousness, and openness to experience have a positive effect on business performance. EM is an important factor in maximising business performance, and entrepreneurial personality traits are needed to support the development of EM.

Implications \& Recommendations: This study contributes to research specifically on the role of EM in improving business performance. In addition, it revealed the importance of the entrepreneurial personality traits of owner/managers in developing EM in SMEs.

Contribution \& Value Added: This study offers an empirically based explanation of entrepreneurial personality traits effects on EM and business performance. It also identifies new opportunities for future research in the field of EM.

$\begin{array}{ll}\text { Article type: } & \text { research article } \\ \text { Keywords: } & \text { entrepreneurial personality traits; entrepreneurial marketing; business performance } \\ \text { JEL codes: } & \text { L26 }\end{array}$

\section{Suggested citation:}

Sarwoko, E., \& Nurfarida, I.N. (2021). Entrepreneurial marketing: Between entrepreneurial personality traits and business performance. Entrepreneurial Business and Economics Review, 9(2), $105-118$. https://doi.org/10.15678/EBER.2021.090207

\section{INTRODUCTION}

Marketing is a fundamental business activity for the achievement of small and medium-sized enterprises' (SME) growth and success (Franco et al., 2014; Reijonen, 2010). Researchers agree that marketing in small firms is different from that of large firms. Marketing in SMEs is unstructured, spontaneous (Gilmore et al., 2001), informal, and reactive to market opportunities (Franco et al., 2014). This is because SMEs have limited resources (Becherer et al., 2012; Sadiku-Dushi et al., 2019), marketing knowledge (Gilmore et al., 2001), and marketing capabilities (Sok et al., 2017). Therefore, traditional marketing theory does not provide a sufficient explanation of marketing in SMEs (Reijonen, 2010). Entrepreneurial marketing (EM) develops as marketing in small companies with limited resources (Sadiku-Dushi et al., 2019).

EM prioritises an 'effectual tactic' in meeting the unique needs of SMEs rather than prioritising marketing concept in general (Beverland \& Lockshin, 2004), in which entrepreneurs recognise, explore, 
and exploit opportunities leading to strategic decisions (Morrish, 2011). EM is more dynamic and sensitive than other approaches in providing opportunities (Mort et al., 2012), and it is more customeroriented: EM can bind customers like family (Sigué \& Biboum, 2019) and is considered to be more low cost and innovative in marketing implementation (Sadiku-Dushi et al., 2019). EM emphasises the role of ideas, intuition, and informal networks in marketing orientation (Stokes, 2000).

Entrepreneurs play an important role in developing opportunities for marketing in SMEs (Whalen et al., 2016). One factor driving the success of entrepreneurs is individual characteristics (Brandstätter, 2011; Lazear, 2005). Through the personality approach, the type of personality causing the success of entrepreneurs can be discovered. According to Nave et al. (2017), personality predicts behaviour, and personality differences will cause differences in behaviour. Entrepreneurial behaviour tends to be informal, unplanned, and reliant on individuals' intuition and power to make things happen (Haworth \& Brearley, 1991). Likewise, EM focuses on entrepreneurs' behaviour (Hills \& Hultman, 2012). EM in small businesses is a part of entrepreneurial behaviour, so it will be influenced by the owner (Franco et al., 2014).

Studies exploring EM were conducted by previous researchers (Miles et al., 2015; Morrish, 2011; Stokes, 2000), while several other scholars used EM as an independent variable in growth and performance. Previous studies empirically shown that EM positively predicts performance (Becherer et al., 2012; Eggers et al., 2020; Fard \& Amiri, 2018; Hamali, 2015; Sadiku-Dushi et al., 2019). Researchers discussed the predictors of EM, such as environmental and organisational influences (Morris et al., 2002), while others studied EM in a strategic context (Sullivan Mort et al., 2012) and in relation to firm capabilities (Whalen et al., 2016). Unfortunately, previous research on EM in SMEs remains limited (Peterson, 2020), especially about the role of entrepreneur on EM. Previous studies showing the role of entrepreneurial personality traits in business performance are still limited. Previous studies did not really support all personality traits dimension towards performance (Franco \& Prata, 2019; Hachana et al., 2018; Leutner et al., 2014; Zhao et al., 2010). Therefore, we address this gap in previous studies by investigating to what extent EM affects business performance, especially in the Indonesian context, while also investigating the role of entrepreneurial personality traits as antecedents of EM. As suggested by Hills and Hultman (2012), more complex research on EM is still required. Therefore, we propose our research model to fill the gap left by previous studies.

This study is based on quantitative data collected from 187 SMEs owner/managers in Indonesia. In developing countries, such as Indonesia, entrepreneurship is the backbone of the national economy because it can contribute to the creation of job opportunities. According to Statistics Indonesia (known locally as BPS), unemployment reached 7.05 million people in 2019, while poverty affected 25.14 million people. Furthermore, 70.49 million people (55.72\% of the population) was working in informal activities (including self-employment, temporary work, freelance). The data shows that Indonesia must be able to reduce the amount of unemployment and poverty. One option is the development of SMEs, as informal business activities were proved to have especially high employment rates. According to Global Entrepreneurship Monitor (GEM) data, Indonesia had perceived opportunities rate (POR) of $54.9 \%$ in 2018 , exceeding the global average of $45.6 \%$. The perceived capabilities rate (PCR) was $64.1 \%$, exceeding the global average of $49.15 \%$ (G.E.M., 2018). Based on the POR and PCR indicators, Indonesia has a strong potential to develop entrepreneurship. Therefore, EM is an important factor for the development of SMEs in Indonesia.

The following section will discuss the literature review to develop a hypothesis. Next, we will explain the measurements, the sampling method, data collection techniques, and data analysis. Then ensues the presentation of data analysis results and their discussion. The paper ends with conclusions and suggestions for further research.

\section{LITERATURE REVIEW}

\section{Entrepreneurial marketing}

EM is the exploitation of opportunities to obtain and retain customers through innovation, leveraging of resources, risk-taking, and value creation (Morris et al., 2002). EM is conducted by small companies and new businesses that utilise available and limited resources (Becherer et al., 2012; Ionita, 2012; Kraus et 
al., 2010; Sadiku-Dushi et al., 2019) by focusing on opportunities to design or develop something new to create value for customers (Hills \& Hultman, 2012; Hisrich \& Ramadani, 2018; Ionita, 2012). When actively applied and disseminated by top management, EM can evolve into an organisational culture that forms the basis for competitive advantages that are difficult to imitate (Whalen et al., 2016).

There is a difference between entrepreneurial marketing and traditional marketing. Traditional marketing is customer-oriented: the method is the 4P or 7P marketing mix, with formal market intelligence. Meanwhile, EM is innovation-oriented: the methods are word-of-mouth, direct selling, and referrals, with market intelligence in the form of informal networking and information gathering (Stokes, 2000). Due to limited resources, SMEs often cannot apply traditional marketing directly. Jones and Rowley (2009) emphasise that that EM is an approach more recommended for SMEs than focusing on sales and promotion. The network referred to in the EMICO framework consists of customer relationships and networks, owner/manager personal communication networks (PCNs), business networks, university networks, and business support networks.

EM emphasises innovation, creativity, and proactiveness (Hisrich \& Ramadani, 2018; Kraus et al., 2010; Solé, 2013). Kilenthong et al. (2015) view the dimensions of EM as consisting of growth and opportunity orientation, customer focus, market analysis, value creation, and proximity to markets. Growth orientation reflects the owner's/manager's ambition to create growth (Kilenthong et al., 2015) as a long-term company goal (Westerlund \& Leminen, 2011). The second EM dimension emphasises opportunities, such as producing products or new processes (Becherer et al., 2012), which has a longterm orientation towards exploiting opportunities (Hills et al., 2008). Network marketing is an important dimension of EM, because owners/managers who rely on the network will obtain information about untapped customer values (Kilenthong et al., 2015). SMEs generally obtain market information informally from customers (Lindh, 2005). The advantage is that the owner/manager is closer to the market and can identify opportunities directly (Kilenthong et al., 2015).

Fard and Amiri (2018) state that EM affects SMEs' market and innovation performance. Franco et al. (2014) argue that EM has an important role in business growth and sustainability. Recent research by Sadiku-Dushi et al. (2019) tests EM dimensions against SMEs' performance, in which opportunity focus, resources leveraging, and value creation had a positive effect on SMEs' performance. Becherer et al. (2012) find that value creation as an EM dimension affects business performance: financial performance, growth, and customer satisfaction. In the context of research on EM in Indonesia, AlManasra et al. (2013) and Hamali (2015) state that EM affects business performance.

Previous studies contributed to the understanding of the relationship between EM and business performance, agreeing that EM is critical to SMEs' business performance. SMEs that implement EM will gain a competitive advantage and will differ from their competitors (Jones \& Rowley, 2009). Thus:

H1: Entrepreneurial marketing has a positive effect on business performance.

\section{Entrepreneurial personality traits}

Personality traits are characteristics of an individual that include emotions, mindset, and behaviour (Mcshane \& Von Glinow, 2010). Personality traits related to entrepreneurial business performance (Hachana et al., 2018) become an important factor that encourages the success of entrepreneurs (Franco \& Prata, 2019) because the personality traits of the owner/manager will affect company strategy (Peterson et al., 2003). Personality will predict behaviour, while differences in a person's personality will lead to differences in behaviour (Nave et al., 2017). Several personality trait models exist but the most popular one is the Big Five (Mcshane \& Von Glinow, 2010; Northouse, 2019): extraversion, agreeableness, conscientiousness, neuroticism, and openness to experience. This study adopts the Big Five model.

Extraversion refers to individuals who enjoy social interaction, are sociable, expressive, and oriented to the outside world (Ciavarella et al., 2004). Extraversion is manifested in full interaction with business activities, the owner/manager is involved in a self-development process (Franco \& Prata, 2019). SMEs' activities involve social interaction, so extraversion plays a role in business performance because extroverted individuals tend to be directly involved in business activities. Franco and Prata 
(2019) and Zhao et al. (2010) report that extraversion is a dimension of the Big Five model related to effective business performance.

Agreeableness is a term used to describe a person who is pleasant, warm, obedient, and trustworthy (Ciavarella et al., 2004). Entrepreneurs with high agreeableness have positive interpersonal relationships (Zhao \& Seibert, 2006) and are more likely to develop business continuity (Baron \& Markman, 2000). Founders with personality traits of agreeableness tend to be more successful in managing family SMEs (Franco \& Prata, 2019). Agreeableness can be a significant predictor of entrepreneurial success (Leutner et al., 2014).

Conscientiousness is an awareness of the company's long-term goals (Ciavarella et al., 2004), an entrepreneur must have a high level of awareness and a sense of optimism to deal with a dynamic business environment (Crane \& Crane, 2007). They must be hard-working and persistent to achieve their goals (Zhao \& Seibert, 2006). Franco and Prata (2019), Zhao et al. (2010), and Hachana et al. (2018) remark that conscientiousness is a dimension of the Big Five model related to effective business performance.

Neurotic individuals are often impulsive; they experience mood swings (Franco \& Prata, 2019), feelings of anxiety, nervousness, sadness, and tension (Brandstätter, 2011), and they tend to lack the courage to take risks and build social capital (Baluku et al., 2016). Entrepreneurs with low neuroticism are self-confident and calm (Zhao \& Seibert, 2006). Franco and Prata (2019) argue that neuroticism is a dimension of the Big Five model that is negatively related to business performance. Zhao et al. (2010) and Hachana et al. (2018) observe that emotional stability is a characteristic of entrepreneurial personality related to effective business performance.

Openness to experience is a personality trait that describes someone who seeks new, imaginative, and creative ideas Zhao et al. (2010). However, it has been negatively related to business performance (Ciavarella et al., 2004), even though the findings Franco and Prata (2019), Hachana et al. (2018), and Zhao et al. (2010) show the opposite to be the case.

Entrepreneurs have specific personal resources that enable them to take advantage of new opportunities by managing their resources (Alvarez \& Busenitz, 2001). One of these personal resources are personality traits. If one's personality traits are valuable, rare, and irreplaceable, this will create a competitive advantage that will drive business performance (Franco \& Prata, 2019). Thus:

H2a: Extraversion has a positive effect on business performance.

H2b: Agreeableness has a positive effect on business performance.

H2c: Conscientiousness has a positive effect on business performance.

H2d: Neuroticism has a positive effect on business performance.

H2e: Openness to experience has a positive effect on business performance.

$E M$ is one of the marketing strategies in small businesses and part of entrepreneurial behaviour. Research conducted by Franco et al. (2014) on SMEs found that marketing activities were reactive to opportunities, meaning that the owner/manager determine the process of decision-making. According to Nave et al. (2017), personality predicts behaviour, and personality differences lead to differences in people's behaviour. EM focuses on entrepreneurs' behaviour (Hills \& Hultman, 2012).

Entrepreneurs use EM behaviours to escalate competitive advantage. These behaviours demonstrate an SME's entrepreneurial approach towards coping with limited (Fard \& Amiri, 2018), SMEs require different or unique resources in order to develop competitive advantage and competitiveness (Fillis \& Rentschler, 2005; Mansion \& Bausch, 2020; Sahid \& Habidin, 2018). This is in line with the resource-based view (RBV) that unique or distinct resources act as drivers towards sustainable competitive advantage (Barney, 1991). The RBV is used in this study to show the role of entrepreneurial personality traits on EM and business performance.

Farrukh et al. (2016) explain that there is a positive relationship between extraversion personality traits and openness to experiences, but also between emotional stability and entrepreneurial behaviour. A direct positive relationship is found between the locus of control personality trait with performance results. Moreover, proactivity has an indirect relationship with financial performance and the quality of relationships through entrepreneurial behaviour (Watson et al., 2020). 
Loveland et al. (2015) state that emotional stability and extraversion are personality traits related to successful sales performance. Caliskan (2019) reports that agreeableness and extraversion are significant predictors in explaining relationship marketing practices. Conscientiousness has a great impact on the preferences of financial and social practices in relationship marketing, while high emotional stability explains the preferences of relationship marketing financial practices only. Thus:

H3a: Extraversion has a positive effect on entrepreneurial marketing.

H3b: Agreeableness has a positive effect on entrepreneurial marketing.

H3c: Conscientiousness has a positive effect on entrepreneurial marketing.

H3d: Neuroticism has a positive effect on entrepreneurial marketing.

H3e: Openness to experience has a positive effect on entrepreneurial marketing.

\section{RESEARCH METHODOLOGY}

\section{Sample and data collection}

Survey method was chosen for data collection in this study. This study involved SMEs' owners/managers with national and international market scope in East Java, Indonesia. According to the Department of Cooperatives and SMEs East Java, there are 1483 SMEs, of which 350 have national and international markets. The sampling technique used simple random sampling. The sample size of 187 owners/managers was obtained from the Slovin formula at a $5 \%$ error level.

Data collection used questionnaires in hard copy form, distributed to owners/managers of UKM. Enumerators were involved in visiting each SME selected as part of the sample to fill out the questionnaire. Data collection ran from September to December 2019. The questionnaire used hard copies with the consideration that not all SMEs in Indonesia actively use email; besides, by visiting directly, the response rate was expected to be better. The returned questionnaires that fulfilled the requirements for analysis numbered 187 out of 200 respondents (response rate $94 \%$ ), consisting of $86 \%$ male and $14 \%$ female respondents. Moreover, $14 \%$ of businesses were running for five to 10 years, $38 \%$ for $10-20$ years, and $48 \%$ for more than 20 years.

\section{Measures}

\section{Entrepreneurial personality traits}

The construct of entrepreneurial personality traits adopted the Big Five theory, measured by five dimensions: extraversion, agreeableness, conscientiousness, neuroticism and openness to experience (Franco \& Prata, 2019). The level of reliability measurement for extraversion was $\alpha=0.957$, agreeableness $\alpha=0.935$, conscientiousness $\alpha=0.922$, neuroticism $\alpha=0.961$, and openness to experience $\alpha$ $=0.937$, which indicated very good reliability.

\section{Entrepreneurial marketing}

The measurement of EM construct was adopted from Kilenthong et al. (2016), who proposed six dimensions: growth orientation, opportunity orientation, total customer focus, value creation through networks, informal market analysis, and market proximity. The level of reliability measurement for EM was $\alpha=0.888$, which indicated very good reliability.

\section{Business performance}

The measurement of the business performance construct was adopted from Choi and Williams (2016), who proposed three dimensions: market share, growth rate, and profitability. The owner/manager was required to compare market share, growth rate, and profitability with competitors for a period of three years. The level of reliability measurement for business performance was $\alpha=0.909$, which indicated very good reliability. All constructs were measured using a five-point Likert scale ranging from strongly disagree (1) to strongly agree (5). 


\section{Data analysis}

Hypothesis testing in this study used structural equation modelling (SEM); SmartPLS 3 software was used for analysis. The advantages of the PLS-SEM method were that the method can test measurement models and structural models and take into account measurement errors. Besides, PLS-SEM offers accurate analysis results for small sample sizes (Hair et al., 2019). This study analysed the causal relationship between the latent variables of entrepreneurial personality traits, EM, and business performance. Therefore, PLS-SEM was an appropriate method if the research objective was theory development and prediction (Hair et al., 2011).

\section{RESULTS AND DISCUSSION}

\section{Descriptive statistics}

Descriptive analysis results in Table 1 show the average level of high business performance. According to the owners/managers, success is seen in the market share by continued increase over the last three years. In addition, according to the owners/managers, the owned or run company experienced sales growth over the past three years. Furthermore, there was an increase in profits over the last three years.

Table 1. Descriptive statistics

\begin{tabular}{|c|c|c|}
\hline Variables & Mean & SD \\
\hline Extraversion (E) & & \\
E1 & 3.209 & 0.682 \\
E2 & 3.214 & 0.737 \\
E3 & 3.299 & 0.667 \\
\hline Agreeableness (A) & & \\
A2 & 2.786 & 0.676 \\
A3 & 2.995 & 0.705 \\
\hline C1 & 2.818 & 0.723 \\
\hline C2 & & \\
C3 & 3.957 & 0.839 \\
N1 & 3.861 & 0.829 \\
N2 & 3.925 & 0.817 \\
N3 & 3.866 & \\
Neuroticism (N) * & 0.636 \\
A1 & 3.840 & 0.736 \\
A2 & 3.920 & 0.645 \\
A3 & 3.668 & \\
EM1 & 3.711 & 0.888 \\
EM2 & 3.727 & 0.809 \\
EM3 & & 0.899 \\
EM4 & 3.048 & \\
EM5 & 3.059 & 0.704 \\
EM6 & 3.176 & 0.740 \\
Openness to experience (O) & 2.807 & 0.825 \\
BP2 & 3.845 & 0.690 \\
BP3 & 3.583 & 0.783 \\
\hline Entepreneurial & & \\
\hline Business performance (BP) & 3.973 & 0.906 \\
\hline & 3.877 & 0.821 \\
\hline & 4.000 & 0.913 \\
\hline
\end{tabular}

Note: * Inverted Item.

Source: own elaboration in SmartPLS (2020). 
In terms of measuring EM of the owner/manager, the SMEs studied have a moderate EM intensity (on the scale of one to five). The dimensions that support EM are owners/managers who have an orientation such that their business continues to experience growth by actively seeking opportunities in national and international markets, but also by looking for product opportunities that are of interest to consumers by conducting market analysis, although informally. Owners/managers admitted that the key to the success of their businesses is the desires and expectations of customers, so the former never cease building relationships with customers, suppliers, and distributors. The SMEs' owners/managers make decisions based on customer feedback. Information from customers is considered when determining marketing strategies and how to make relationships with customers more effective.

The results from the measurement of entrepreneurial personality traits indicate that the SMEs owners/managers already had personal values that supported entrepreneurial behaviour, that is they scored highly in conscientiousness, and openness to experience, and moderately on extraversion and agreeableness, low on neuroticism.

\section{Measurement model}

Model estimation and research hypothesis testing used SmartPLS software. Table 2 presents the loading values and $t$-values for each construct analysed in the study. The criteria used for loading values was above 0.7 , indicating that the construct can explain the variant of the indicator, and the indicator has a satisfactory level of reliability (Sarstedt et al., 2017). Loading values for the five indicators of entrepreneurial personality traits, the five indicators of EM and the three indicators of business performance shows that each has a loading value of $>0.7$ and a significant $t$-value ( $t$-value $>1.96$ ). Only one indicator of EM (opportunity orientation) has a loading value of $<0.7$ but a significant $t$ value. According to (Hulland, 1999), the minimum acceptable loading value is 0.4 ; thus, the opportunity orientation indicator remains acceptable.

The assessment of composite reliability to measure internal consistency is presented in Table 3. The criterion of composite reliability must be greater than 0.7 (Hair Jr et al., 2014) for the model to have good internal reliability. All constructs have a composite reliability above 0.7 , which indicates good reliability. Furthermore, to evaluate convergent validity, we look for average variance extracted (AVE) criteria greater than 0.5 (Hair Jr et al., 2014). The AVE value in each construct is greater than 0.5; thus, all constructs fulfil the convergent validity criteria. Meanwhile, discriminant validity uses AVE criteria in which the AVE of each latent construct must be higher than the highest squared correlation between latent constructs (Hair Jr et al., 2014). The AVE value is shown by the numbers on the diagonal in Table 3, wherein the AVE value of each latent construct is greater than the highest square correlation between latent constructs. Therefore, the model meets the discriminant validity criteria.

\section{Structural model}

Structural models were used to evaluate causal relationships between constructs in the model. The criterion for evaluating the model structure is the coefficient of determination $R^{2}$. The test results showed that $R^{2}=0.696$ for business performance and 0.537 for $E M$, explaining $69.6 \%$ of business performance variance and $53.7 \%$ of EM variance. The evaluation results indicated that the business performance and EM coefficients in the model were categorised as fairly good.

The assessment of the quality of the model is from the value of cross-validated redundancy $\left(Q^{2}\right)$ to assess the predictive relevance of the model. The value of $Q^{2}>0$ indicates the accuracy of the model's prediction (Hair et al., 2011). The $\mathrm{Q}^{2}$ value for the BP construct is 0.522 and for the EM construct is 0.296 , so the exogenous construct has predictive relevance for the endogenous construct. 
Table 2. Constructs and loading factors

\begin{tabular}{|c|c|c|}
\hline Constructs & Loadings & t-value \\
\hline \multicolumn{3}{|l|}{ Extraversion (E) } \\
\hline E1 & 0.959 & 132.980 \\
\hline E2 & 0.921 & 58.937 \\
\hline E3 & 0.935 & 80.152 \\
\hline \multicolumn{3}{|l|}{ Agreeableness (A) } \\
\hline A1 & 0.952 & 82.464 \\
\hline $\mathrm{A} 2$ & 0.858 & 29.492 \\
\hline $\mathrm{A} 3$ & 0.916 & 41.270 \\
\hline \multicolumn{3}{|l|}{ Conscientiousness (C) } \\
\hline $\mathrm{C} 1$ & 0.949 & 79.003 \\
\hline $\mathrm{C} 2$ & 0.938 & 80.388 \\
\hline $\mathrm{C} 3$ & 0.946 & 74.401 \\
\hline \multicolumn{3}{|l|}{ Neuroticism (N) } \\
\hline N1 & 0.940 & 65.431 \\
\hline N2 & 0.805 & 16.914 \\
\hline N3 & 0.930 & 64.545 \\
\hline \multicolumn{3}{|c|}{ Openness to experience (0) } \\
\hline 01 & 0.942 & 53.197 \\
\hline $\mathrm{O} 2$ & 0.881 & 26.218 \\
\hline $\mathrm{O3}$ & 0.915 & 54.828 \\
\hline \multicolumn{3}{|c|}{ Entrepreneurial marketing } \\
\hline EM1 & 0.573 & 9.943 \\
\hline EM2 & 0.802 & 30.329 \\
\hline EM3 & 0.751 & 23.966 \\
\hline EM4 & 0.767 & 19.259 \\
\hline EM5 & 0.846 & 48.594 \\
\hline EM6 & 0.776 & 23.116 \\
\hline \multicolumn{3}{|l|}{ Business performance } \\
\hline BP1 & 0.887 & 51.049 \\
\hline BP2 & 0.894 & 63.624 \\
\hline BP3 & 0.850 & 32.672 \\
\hline
\end{tabular}

Source: own elaboration in SmartPLS (2020).

Table 3. Evaluation on Measurement Model

\begin{tabular}{|l|c|c|c|c|c|c|c|c|}
\hline \multicolumn{1}{|c|}{ Constructs } & $\begin{array}{c}\text { Composite } \\
\text { Reliability }\end{array}$ & E & A & C & N & O & EM & BP \\
\hline Extraversion (E) & 0.957 & $\mathbf{0 . 9 3 8}$ & & & & & & \\
Agreeableness (A) & 0.935 & $\mathbf{0 . 2 9 8}$ & $\mathbf{0 . 9 0 9}$ & & & & & \\
Conscientiousness (C) & 0.961 & $\mathbf{0 . 4 6 0}$ & $\mathbf{0 . 3 6 2}$ & $\mathbf{0 . 9 4 4}$ & & & & \\
Neuroticism (N) & 0.922 & $\mathbf{0 . 2 6 1}$ & $\mathbf{0 . 4 2 9}$ & $\mathbf{0 . 2 8 4}$ & $\mathbf{0 . 8 9 4}$ & & & \\
Openness to experience (O) & 0.937 & $\mathbf{0 . 3 4 3}$ & $\mathbf{0 . 3 7 0}$ & $\mathbf{0 . 4 6 6}$ & $\mathbf{0 . 4 0 8}$ & $\mathbf{0 . 9 1 3}$ & & \\
Entrepreneurial Marketing (EM) & 0.888 & $\mathbf{0 . 5 6 2}$ & $\mathbf{0 . 4 8 2}$ & $\mathbf{0 . 5 9 3}$ & $\mathbf{0 . 4 0 4}$ & $\mathbf{0 . 4 6 8}$ & $\mathbf{0 . 7 5 7}$ & \\
Business Performance (BP) & 0.909 & $\mathbf{0 . 5 4 5}$ & $\mathbf{0 . 4 4 5}$ & $\mathbf{0 . 7 2 5}$ & $\mathbf{0 . 3 7 7}$ & $\mathbf{0 . 6 1 3}$ & $\mathbf{0 . 6 8 8}$ & $\mathbf{0 . 8 7 7}$ \\
\hline
\end{tabular}

Source: own elaboration in SmartPLS (2020).

\section{Hypotheses testing and scientific discussion}

Table 4 presents the path coefficient values that show causal relationships between constructs, The $p$ value for testing the significance of causal relationships between constructs, all of which meet the criterion for significant ( $p$-value $<0.05$ ) (Hair et al., 2011). 
Table 4. Hypothesis testing

\begin{tabular}{|l|c|c|}
\hline \multicolumn{1}{|c|}{ Relationship } & Path coefficient & P values \\
\hline EM $\rightarrow$ BP & 0.238 & 0.000 \\
Extraversion $\rightarrow$ BP & 0.129 & 0.023 \\
Agreeableness $\rightarrow$ BP & 0.054 & 0.338 \\
Conscientiousness $\rightarrow$ BP & 0.382 & 0.000 \\
Neuroticism $\rightarrow$ BP & 0.012 & 0.818 \\
Openness $\rightarrow$ BP & 0.254 & 0.000 \\
Extraversion $\rightarrow$ EM & 0.299 & 0.000 \\
Agreeableness $\rightarrow$ EM & 0.196 & 0.001 \\
Conscientiousness $\rightarrow$ EM & 0.303 & 0.000 \\
Neuroticism $\rightarrow$ EM & 0.112 & 0.054 \\
Openness $\rightarrow$ EM & 0.106 & 0.062 \\
\hline
\end{tabular}

Source: own elaboration in SmartPLS (2020).

The results indicated that EM has a positive and significant effect on business performance; $\mathrm{H} 1$ was confirmed. This agrees with previous research (Al-Manasra et al., 2013; Fard \& Amiri, 2018; Hamali, 2015 ) that affirms the effect of EM on SMEs' performance. Owners/managers who are oriented towards business growth will prioritise long-term business growth over short-term profit (Westerlund \& Leminen, 2011), so they make an effort to seek new opportunities and realise them. Therefore, there is an increase in market capacity, sales, or business scale. Small and medium-sized enterprises that implement EM will gain a competitive advantage and will be distinct from their competitors (Jones \& Rowley, 2009). Furthermore, owners/managers make the customer an important component of their business, always focusing on fulfilling their desires and request (Hills \& Hultman, 2012; Hisrich \& Ramadani, 2018). Owners/managers actively use market and customer information when making decisions with regard to new products and services (Kilenthong et al., 2015). In general, within SMEs, market information is obtained informally by the owners/managers. They will introduce new products and services if customer demand suggests that they should.

The results showed that business performance is determined by entrepreneurial personality traits. Of the Big Five, extraversion, conscientiousness, and openness to experience are elements of entrepreneurial personality positively related to business performance. Therefore, $\mathrm{H} 2 \mathrm{a}, \mathrm{H} 2 \mathrm{c}$, and $\mathrm{H} 2 \mathrm{e}$ were confirmed, while $\mathrm{H} 2 \mathrm{~b}$ and $\mathrm{H} 2 \mathrm{~d}$ were not. The present study indicates that owners/managers who succeed in building a business have personality traits of extraversion, conscientiousness, and openness to experience. Extraversion is an entrepreneurial personality trait with the strongest relationship with business performance; that is, it plays the most important role in achieving SME success.

The owners/managers of SMEs have high extraversion so they tend to be directly involved in business activities (Leutner et al., 2014), they carry out social interactions with customers and suppliers. Such an engagement helps to raise awareness of the importance of building networks with external resources (Hachana et al., 2018). The owners always seek opportunities to start new projects, they dare to set challenging goals, and they exhibit the energy needed to move forward. This can be achieved best if they are extraverts. The results of the present study support the findings of Franco and Prata (2019) and Zhao et al. (2010). These authors state that extraversion is the dimension of the Big Five personality model needed for success.

Conscientiousness has an effect on business performance because a person who possesses it has a sense of responsibility and attention to detail. Such people run their companies in a principled manner. They work hard and persistently to achieve their goals (Zhao \& Seibert, 2006), which ensures long-term business continuity (Ciavarella et al., 2004). Openness to experience has an effect on performance: entrepreneurs with imaginative and creative characters enjoy discovering new ideas (Zhao et al., 2010). Conscientiousness personality traits are clearly a competitive advantage when it comes to business performance.

The present study has elaborated the relationship between entrepreneurial personality traits and business performance, and in doing so, it has extended our understanding of the importance of social aspects of personality entrepreneurship in fostering unique characteristics of SMEs (Darcy et al., 2014). 
We have argued that entrepreneurs with extraversion, conscientiousness, and openness to experience provide their companies with unique characteristics or critical resources for competitive advantage, because management in SMEs is usually conducted in a highly personalised manner and is strongly influenced by personality (Beaver \& Jennings, 2005).

The results of the study showed that extraversion, agreeableness, and conscientiousness are positively associated with entrepreneurial marketing, so $\mathrm{H} 3 \mathrm{a}, \mathrm{H} 3 \mathrm{~b}$, and $\mathrm{H} 3 \mathrm{c}$ were confirmed, while $\mathrm{H} 3 \mathrm{~d}$ and $\mathrm{H} 3 \mathrm{e}$ could not have been. The findings indicated that entrepreneurs with high levels of extraversion, agreeableness, and conscientiousness support EM in SMEs. Personality predicts behaviour, and personality differences will lead to differences in people's behaviours (Nave et al., 2017). One manifestation of entrepreneurial behaviour is EM (Hills et al., 2008). The results of the study support the findings of Loveland et al. (2015) that extraversion personality traits are related to sales performance. Agreeableness, extraversion, and conscientiousness are significant predictors of successful relationship marketing practices (Caliskan, 2019). Entrepreneurial personality traits predict human behaviour, including entrepreneurship (Ahmad, 2010). Therefore, our findings indicate that extraversion, agreeableness, and conscientiousness will encourage entrepreneurial behaviour in general (Farrukh et al., 2016) and EM in particular.

The present study offers an insight into the nature of SME owner/managers who possess the entrepreneurial personality traits of extraversion, conscientiousness, and openness to experience, and who develop their EM capabilities to increase competitive advantage. This perspective supports the resource based view (RBV), which argues that EM and entrepreneurial personality are unique resources that drive business performance and sustainable competitive advantage (Barney, 1991). The present study has proven that entrepreneurial personality traits are antecedents of EM, that extraversion, agreeableness, and conscientiousness in particular play a role in increasing EM, and that EM can drive business performance.

\section{CONCLUSIONS}

The present study investigated the role of EM in business performance and the role of entrepreneurial personality traits as antecedents of EM. The results showed that EM has a positive effect on business performance, and that SMEs focused on growth, opportunities, customers, networks, informal market analysis, and market proximity in their marketing activities can improve business performance. This can be achieved more easily if the SME owner/manager shows traits of extraversion, agreeableness, and conscientiousness. Another finding was that, amongst the Big Five entrepreneurial personality traits, extraversion, conscientiousness, and openness to experience determine business performance success. Therefore, extravert and conscientious SME owners/managers who are open to experience will influence the implementation of EM in SMEs, which will improve their business performance.

One implication of the present study for management is that entrepreneurs should have a set of EM practices that maintain or improve business performance (Kilenthong et al., 2015), because not all the principles in marketing literature can be used in small businesses (Mort et al., 2012). Another implication is that extraversion, conscientiousness, and openness to experience determine business performance. Finally, successful entrepreneurship is inseparable from the characteristics of the individual (Stokes, 2000). Therefore, it is important that SMEs foster extraversion, conscientiousness, and openness to experience.

This research has limitations. The study was conducted only on SMEs in Indonesia. Replication studies in several other countries are likely to yield different results, but allowing comparison with the results of this study may open up new areas for further research. Secondly, business performance in this study was measured by collecting subjective opinions of owners/managers using market share, growth rate, and profitability measures compared to competitors over three years (qualitative measures). Further research could add a quantitative measure from their financial statements or SMEs internal notes as a measurement of business performance. 


\section{REFERENCES}

Ahmad, H.M. (2010). Personality traits among entrepreneurial and professional CEOs in SMEs. International Journal of Business and Management, 5(9), 203.

Al-Manasra, E., Al-Zyadat, M.A., Al-Awamreh, M.A., \& Alnsour, M.S. (2013). Linking entrepreneurial marketing and performance indicators in Jordanian hotel industry. Journal of Management Research, 5(3), 86-94.

Alvarez, S.A., \& Busenitz, L.W. (2001). The entrepreneurship of resource-based theory. Journal of Management, 27(6), 755-775.

Baluku, M.M., Kikooma, J.F., \& Kibanja, G.M. (2016). Does personality of owners of micro enterprises matter for the relationship between startup capital and entrepreneurial success?. African Journal of Business Management, 10(1), 13-23.

Barney, J. (1991). Firm Resources and Sustained Competitive Advantage. Journal of Management, 17(1), 99-120. https://doi.org/10.1177/014920639101700108

Baron, R.A., \& Markman, G.D. (2000). Beyond social capital: How social skills can enhance entrepreneurs' success. Academy of Management Perspectives, 14(1), 106-116.

Beaver, G., \& Jennings, P. (2005). Competitive advantage and entrepreneurial power: The dark side of entrepreneurship. Journal of Small Business and Enterprise Development, 12(1), 9-23. https://doi.org/10.1108/14626000510579617

Becherer, R.C., Helms, M.M., \& McDonald, J.P. (2012). The effect of entrepreneurial marketing on outcome goals in SMEs. New England Journal of Entrepreneurship, 15(1), 7-18. https://doi.org/10.1108/neje-15-01-2012-b001

Beverland, M., \& Lockshin, L.S. (2004). Crafting a competitive advantage: tempering entrepreneurial action with positioning-based values. Qualitative Market Research: an International Journal, 7(3), $172-182$. https://doi.org/10.1108/13522750410540182

Brandstätter, H. (2011). Personality aspects of entrepreneurship: A look at five meta-analyses. Personality and Individual Differences, 51(3), 222-230. https://doi.org/10.1016/j.paid.2010.07.007

Caliskan, A. (2019). Applying the right relationship marketing strategy through big five personality traits. Journal of Relationship Marketing, 18(3), 196-215. https://doi.org/10.1080/15332667.2019.1589241Choi, S.B., \& Williams, C. (2016). Entrepreneurial orientation and performance: mediating effects of technology and marketing action across industry types. Industry and Innovation, 23(8), 673-693. https://doi.org/10.1080/13662716.2016.1208552

Ciavarella, M.A., Buchholtz, A.K., Riordan, C.M., Gatewood, R.D., \& Stokes, G.S. (2004). The Big Five and venture survival: Is there a linkage?. Journal of Business Venturing, 19(4), 465-483. https://doi.org/10.1016/j.jbusvent.2003.03.001

Crane, F.G., \& Crane, E.C. (2007). Dispositional optimism and entrepreneurial success. The Psychologist-Manager Journal, 10(1), 13-25.

Darcy, C., Hill, J., McCabe, T.J., \& McGovern, P. (2014). A consideration of organisational sustainability in the SME context: A resource-based view and composite model. European Journal of Training and Development, 38(5), 398-414. https://doi.org/10.1108/EJTD-10-2013-0108

Eggers, F., Niemand, T., Kraus, S., \& Breier, M. (2020). Developing a scale for entrepreneurial marketing: Revealing its inner frame and prediction of performance. Journal of Business Research, 113, 72-82. https://doi.org/10.1016/j.jbusres.2018.11.051

Fard, M.H., \& Amiri, N.S. (2018). The effect of entrepreneurial marketing on halal food SMEs performance. Journal of Islamic Marketing, 9(3), 598-620. https://doi.org/10.1108/JIMA-12-2016-0097

Farrukh, M., Ying, C.W., \& Mansori, S. (2016). Intrapreneurial behavior: an empirical investigation of personality traits. Management \& Marketing. Challenges for the Knowledge Society, 11(4), 597-609. https://doi.org/10.1515/mmcks-2016-0018

Fillis, I., \& Rentschler, R. (2005). Creative marketing: An extended metaphor for marketing in a new age: Springer.

Franco, M., de Fátima Santos, M., Ramalho, I., \& Nunes, C. (2014). An exploratory study of entrepreneurial marketing in SMEs: The role of the founder-entrepreneur. Journal of Small Business and Enterprise Development, 21(2), 265-283. https://doi.org/10.1108/JSBED-10-2012-0112

Franco, M.R., \& Prata, M. (2019). Influence of the individual characteristics and personality traits of the founder on the performance of family SMEs. European Journal of International Management, 13(1), 1-1. https://doi.org/10.1504/ejim.2017.10014114 
G.E.M. (2018). Entrepreneurial Behaviour and Attitudes. Retrieved from https://www.gemconsortium.org/ economy-profiles/indonesia on 19 November 2020.

Gilmore, A., Carson, D., \& Grant, K. (2001). SME marketing in practice. Marketing Intelligence \& Planning, 19(1), 6-11.

Hachana, R., Berraies, S., \& Ftiti, Z. (2018). Identifying personality traits associated with entrepreneurial success: does gender matter?. Journal of Innovation Economics Management(3), 169-193.

Hair, J.F., Ringle, C.M., \& Sarstedt, M. (2011). PLS-SEM: Indeed a silver bullet. Journal of Marketing Theory and Practice, 19(2), 139-152.

Hair, J.F., Risher, J.J., Sarstedt, M., \& Ringle, C.M. (2019). When to use and how to report the results of PLS-SEM. European Business Review. 31(1), 2-24. https://doi.org/10.1108/EBR-11-2018-0203

Hair Jr, J.F., Sarstedt, M., Hopkins, L., \& Kuppelwieser, V.G. (2014). Partial least squares structural equation modeling (PLS-SEM). European Business Review. 26(2), 106-121. https://doi.org/10.1108/EBR-10-2013-0128

Hamali, S. (2015). The effect of entrepreneurial marketing on business performance: Small garment industry in Bandung City, Indonesia. Developing Country Studies, 5(1), 2225-0565.

Haworth, J.M., \& Brearley, S.A. (1991). The entrepreneurial personality: concepts, cases and categories. Routledge.

Hills, G.E., \& Hultman, C.M. (2012). Academic Roots: The Past and Present of Entrepreneurial Marketing. Journal of Small Business \& Entrepreneurship, 24(1), 1-10. https://doi.org/10.1080/08276331.2011.10593521

Hills, G.E., Hultman, C.M., \& Miles, M.P. (2008). The evolution and development of entrepreneurial marketing. Journal of Small Business Management, 46(1), 99-112.

Hisrich, R.D., \& Ramadani, V. (2018). Entrepreneurial Marketing: A Practical Managerial Approach: Edward Elgar Publishing.

Hulland, J. (1999). Use of partial least squares (PLS) in strategic management research: A review of four recent studies. Strategic Management Journal, 20(2), 195-204.

Ionita, D. (2012). Entrepreneurial marketing: A new approach for challenging times. Management \& Marketing, 7(1), 131.

Jones, R., \& Rowley, J. (2009). Presentation of a generic EMICO framework for research exploration of entrepreneurial marketing in SMEs. Journal of Research in Marketing and Entrepreneurship, 11(1), 5-21.

Kilenthong, P., Hills, G.E., \& Hultman, C.M. (2015). An empirical investigation of entrepreneurial marketing dimensions. Journal of International Marketing Strategy, 3(1), 1-18.

Kilenthong, P., Hultman, C.M., \& Hills, G.E. (2016). Entrepreneurial marketing behaviours: impact of firm age, firm size and firm's founder. Journal of Research in Marketing and Entrepreneurship, 18(1), 127-145. https://doi.org/10.1108/jrme-05-2015-0029

Kraus, S., Harms, R., \& Fink, M. (2010). Entrepreneurial marketing: moving beyond marketing in new ventures. International Journal of Entrepreneurship and Innovation Management, 11(1), 19-19. https://doi.org/10.1007/s003920050017

Lazear, E.P. (2005). Entrepreneurship. Journal of Labor Economics, 23(4), 649-680. https://doi.org/10.1086/491605

Leutner, F., Ahmetoglu, G., Akhtar, R., \& Chamorro-Premuzic, T. (2014). The relationship between the entrepreneurial personality and the Big Five personality traits. Personality and Individual Differences, 63(6), 58-63.

Lindh, K. (2005). The Nature of Entrepreneurial Marketing: A Case Study of an Art Museum. Research at the Marketing/Entrepreneurship Interface. University of Illinois at Chicago, Chicago, IL.

Loveland, J.M., Lounsbury, J.W., Park, S.-H., \& Jackson, D.W. (2015). Are salespeople born or made? Biology, personality, and the career satisfaction of salespeople. Journal of Business \& Industrial Marketing.

Mansion, S.E., \& Bausch, A. (2020). Intangible assets and SMEs export behavior: a meta-analytical perspective. Small Business Economics, 55(3), 727-760. https://doi.org/10.1007/s11187-019-00182-5

McShane, S., \& Von Glinow, M.A. (2010). Organizational behaviour: Emerging knowledge and practice for the real world: McGraw-Hill/Irwin.

Miles, M., Gilmore, A., Harrigan, P., Lewis, G., \& Sethna, Z. (2015). Exploring entrepreneurial marketing. Journal of Strategic Marketing, 23(2), 94-111. https://doi.org/10.1080/0965254X.2014.914069

Morris, M.H., Schindehutte, M., \& LaForge, R.W. (2002). Entrepreneurial Marketing: A Construct for Integrating Emerging Entrepreneurship and Marketing Perspectives. Journal of Marketing Theory and Practice, 10(4), 119. https://doi.org/10.1080/10696679.2002.11501922 
Morrish, S.C. (2011). Entrepreneurial marketing: a strategy for the twenty-first century?. Journal of Research in Marketing and Entrepreneurship, 13(2), 110-119. https://doi.org/10.1108/14715201111176390

Mort, G.S., Weerawardena, J., \& Liesch, P. (2012). Advancing entrepreneurial marketing: Evidence from born global firms. European Journal of Marketing, 46(3-4), 542-561. https://doi.org/10.1108/03090561211202602

Nave, C.S., Edmonds, G.W., Hampson, S.E., Murzyn, T., \& Sauerberger, K.S. (2017). From elementary school to midlife: Childhood personality predicts behavior during cognitive testing over four decades later. Journal of Research in Personality, 67(4), 183-189. https://doi.org/10.1016/j.jrp.2016.10.001

Northouse, P.G. (2019). Leadership: Theory and Practice: Sage publications.

Peterson, M. (2020). Modeling country entrepreneurial activity to inform entrepreneurial-marketing research. Journal of Business Research, 113, 105-116. https://doi.org/10.1016/j.jbusres.2018.11.042

Peterson, R.S., Smith, D.B., Martorana, P.V., \& Owens, P.D. (2003). The impact of chief executive officer personality on top management team dynamics: One mechanism by which leadership affects organizational performance. Journal of Applied Psychology, 88(5), 795.

Reijonen, H. (2010). Do all SMEs practise same kind of marketing?. Journal of Small Business and Enterprise Development, 17(2), 279-293. https://doi.org/10.1108/14626001011041274

Sadiku-Dushi, N., Dana, L.O.P., \& Ramadani, V. (2019). Entrepreneurial marketing dimensions and SMEs performance. Journal of Business Research, 100(7), 86-99. https://doi.org/10.1016/j.jbusres.2019.03.025

Sahid, S., \& Habidin, N.F. (2018). Exploring measurement model for entrepreneurial marketing construct: $A$ marketing for SME's. International Journal of Supply Chain Management, 7(6), 674-683.

Sarstedt, M., Ringle, C.M., \& Hair, J.F. (2017). Partial Least Squares Structural Equation Modeling. Springer International Publishing.

Sigué, S.P., \& Biboum, A.D. (2019). Entrepreneurial Marketing and Social Networking in Small and Medium Service Enterprises: A Case Study into Business Dealings in Cameroon. Journal of African Business, 21(3), 117. https://doi.org/10.1080/15228916.2019.1625022

Sok, P., Snell, L., Lee, W.J.T., \& Sok, K.M. (2017). Linking entrepreneurial orientation and small service firm performance through marketing resources and marketing capability. Journal of Service Theory and Practice, 27(1), 231-249. https://doi.org/10.1108/JSTP-01-2016-0001

Solé, M. (2013). Entrepreneurial marketing: conceptual exploration and link to performance. Journal of Research in Marketing and Entrepreneurship, 15(1), 23-38. https://doi.org/10.1108/jrme-07-2012-0020

Stokes, D. (2000). Putting Entrepreneurship into Marketing: The Processes of Entrepreneurial Marketing. Journal of Research in Marketing and Entrepreneurship, 2(1), 1-16. https://doi.org/10.1108/14715200080001536

Sullivan Mort, G., Weerawardena, J., \& Liesch, P. (2012). Advancing entrepreneurial marketing: Evidence from born global firms. European Journal of Marketing, 46(3/4), 542-561. https://doi.org/10.1108/03090561211202602

Watson, A., Dada, O., López-Fernández, B., \& Perrigot, R. (2020). The influence of entrepreneurial personality on franchisee performance: A cross-cultural analysis. International Small Business Journal, 1-24. https://doi.org/10.1177/0266242620914520

Westerlund, M., \& Leminen, S. (2011). In praise of entrepreneurial marketing: a study on entrepreneur-led firms. Journal of Research in Marketing and Entrepreneurship, 10(1), 70-75.

Whalen, P., Uslay, C., Pascal, V.J., Omura, G., McAuley, A., Kasouf, C.J., Jones, R., Hultman, C.M., Hills, G.E., Hansen, D.J., Gilmore,A., Giglierano, J., Eggers, F., \& Deacon, J. (2016). Anatomy of competitive advantage: towards a contingency theory of entrepreneurial marketing. Journal of Strategic Marketing, 24(1), 5-19. https://doi.org/10.1080/0965254X.2015.1035036

Zhao, H., \& Seibert, S.E. (2006). The big five personality dimensions and entrepreneurial status: A meta-analytical review. Journal of Applied Psychology, 91(2), 259.

Zhao, H., Seibert, S.E., \& Lumpkin, G.T. (2010). The relationship of personality to entrepreneurial intentions and performance: A meta-analytic review. Journal of Management, 36(2), 381-404. https://doi.org/10.1177/0149206309335187 


\section{Authors}

The contribution of each author is equal to 50\%. Endi Sarwoko prepared the introduction, literature review, methods, and discussion, while Iva Nurdiana Nurfarida prepared the statistical elaborations and results.

\section{Endi Sarwoko}

Assistant Professor at the Department of Management, Universitas Kanjuruhan Malang, Indonesia. Doctor in Management Science (Brawijaya University, Indonesia). His research interests include entrepreneurship, human resources management, and organisational behaviour.

Correspondence to: Dr Endi Sarwoko, Universitas Kanjuruhan Malang, Indonesia, Jl. S. Supriadi 48 Malang, Indonesia; e-mail: endiswk@unikama.ac.id

ORCID (1) http://orcid.org/0000-0002-1573-9639

\section{Iva Nurdiana Nurfarida}

Junior lecturer at the Department of Management, Universitas Kanjuruhan Malang, Indonesia. Her research interests include marketing and business innovation.

Correspondence to: Iva Nurdiana Nurfarida, Universitas Kanjuruhan Malang, Indonesia, Jl. S. Supriadi 48 Malang, Indonesia; e-mail: ivanurdiana@unikama.ac.id

ORCID (1) http://orcid.org/0000-0002-8147-4851

\section{Acknowledgements and Financial Disclosure}

The research was supported by the Research and Community Service Institute, Universitas Kanjuruhan Malang, Indonesia.

\section{Conflict of Interest}

The authors declare that the research was conducted in the absence of any commercial or financial relationships that could be construed as a potential conflict of interest.

\section{Copyright and License}

This article is published under the terms of the Creative Commons

Attribution - NoDerivs (CC BY-ND 4.0) License

http://creativecommons.org/licenses/by-nd/4.0/ 